\title{
Influences of Overland Runoff and River Flow on As Contents in Jiaozhou Bay
}

\author{
Dongfang Yang, 2, 3, a , Fengyou Wang, 2, b, c, Sixi Zhu ${ }^{1,2}$, Yunjie $\mathrm{Wu}^{1,2}$ and Xiuqin Yang ${ }^{1,2}$ \\ ${ }^{1}$ Research Center for Karst Wetland Ecology, Guizhou Minzu University, Guizhou Guiyang, Guizhou, \\ Guiyang, China \\ ${ }^{2}$ College of Chemistry and Environmental Science, Guizhou Minzu University, Shanghai, 550025, China \\ ${ }^{3}$ North China Sea Environmental Monitoring Center, SOA, Qingdao 266033, China \\ adfyang_dfyang@126.com, 'wangfy2001@yahoo.com.cn \\ ${ }^{\mathrm{b}}$ Corresponding author
}

Keywords: Arsenic (As), Distribution, Source, Influence, Jiaozhou Bay.

\begin{abstract}
Using investigation data on as in 29 sampling sites in Jiaozhou Bay in April and August 1981, this paper researched the contents and horizontal distributions of As. Results showed that As contents in April and August 1981 were $1.02-2.70 \mu \mathrm{g} \mathrm{L}^{-1}$ and 1.00-2.66 $\mu \mathrm{g} \mathrm{L}{ }^{-1}$, respectively. The pollution level of As in Jiaozhou Bay 1981 was very slight. High As contents regions were in the coastal waters in northeast, east and north of the bay. The major as sources were overland runoff and river flow, whose source strengths were 2.06-2.20 $\mathrm{g} \mathrm{L}^{-1}$ and 2.00-2.70 $\mu \mathrm{g} \mathrm{L}{ }^{-1}$, respectively. The source strengths of $\mathrm{Cd}$ inputs were very closed in different months as $2.00-2.70 \mu \mathrm{g} \mathrm{L}^{-1}$. This indicated that the inputs of As from different sources were continuous and stable. Hence, more attentions should be payed to monitor the contents of As in overland runoff and river flow.
\end{abstract}

\section{Introduction}

As has been widely used in industry and agriculture, and As pollution has been one of the critical environmental issues in many countries and regions. Ocean is the sink of pollutant, and as a result many marine bays have been polluted by As [1-3]. Furthermore, the excessive existence of As is toxic to organism. Hence, researching the pollution level and major sources of As in marine waters is essential to environmental protection. Using investigation data on As in 29 sampling sites in Jiaozhou Bay in April and August 1981, this paper researched the contents and horizontal distributions of As. The aim of this paper was to provide basis for researching on the migration process of As in marine bay.

\section{Study area and data collection}

Jiaozhou Bay is located in the south of Shandong Province, eastern China $\left(35^{\circ} 55^{\prime}-36^{\circ} 18^{\prime} \mathrm{N}\right.$, $120^{\circ} 04^{\prime}-120^{\circ} 23^{\prime} \mathrm{E}$ ), with the total area and average water depth of $446 \mathrm{~km} 2$ and $7 \mathrm{~m}$, respectively. The bay mouth is very narrow $(3 \mathrm{~km})$ between Tuandao and Xuejiadao, and is connected to the Yellow Sea. There are a dozen of rivers, and the major rivers include Dagu River, Haibo Rriver, Licun Rriver, and Loushan Rriver etc. All of which are seasonal rivers strongly impacted by seasonal factors [4-5].

The investigation on As in surface waters in Jiaozhou Bay was carried on in April and August 1981 in 29 sampling sites (i.e., A1, A2, A3, A5, A6, A7, A8, B1, B2, B3, B4, B5, C1, C2, C3, C4, C5, C6, C7, C8, D1, D2, D3, D4, D5, D6, D7, D8 and D9) (Fig. 1). As in waters was sampled and monitored follow by National Specification for Marine Monitoring [6]. 


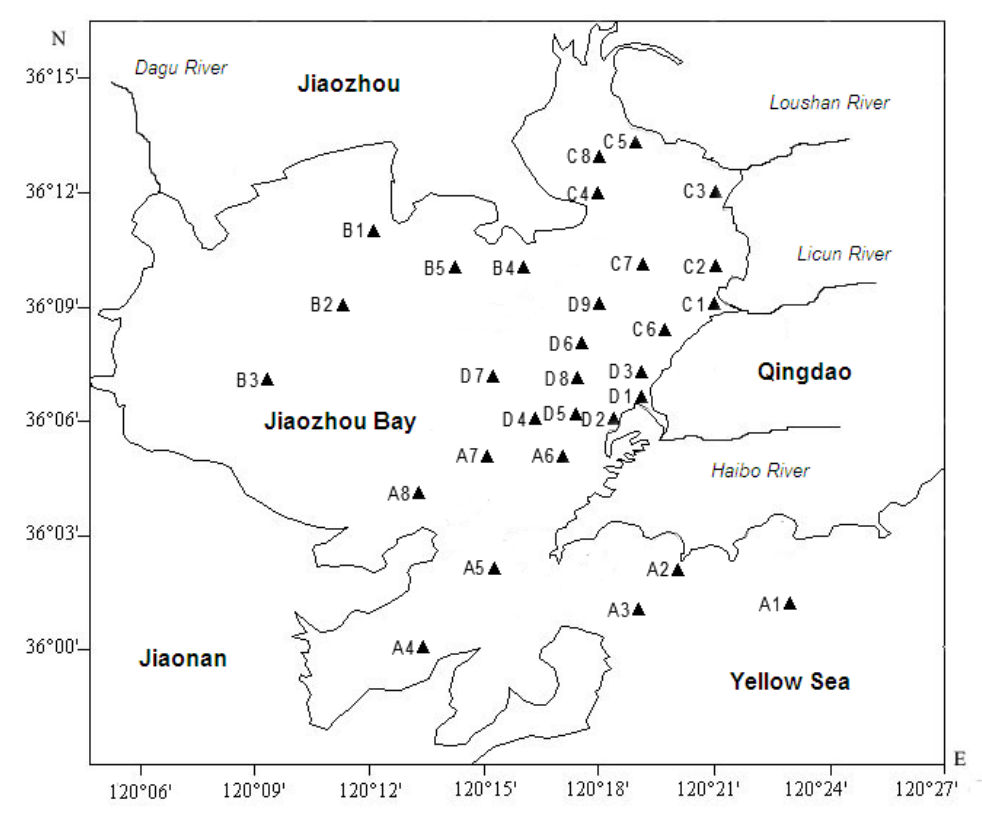

Fig. 1 Geographic location and sampling sites of Jiaozhou Bay

\section{Results}

As contents in April 1981 were 1.02-2.70 $\mu \mathrm{g}$ L-1. The first high value of As contents was in Site D1 $(2.70 \mu \mathrm{g} \mathrm{L-1})$ in the estuary of Haibo River, and the contour lines of As contents were forming a series of semi-concentric circles, and were decreasing from the high value center to the bay mouth $(1.68 \mu \mathrm{g} \mathrm{L}-1)$ and the open waters (1.26 $\mu \mathrm{g} \mathrm{L-1)}$ (Fig. 2). The second high value of As contents was in Site C1 (2.00 $\mu \mathrm{g} \mathrm{L-1)}$ in the estuary of Licun River, and the contour lines of As contents were forming a series of semi-concentric circles, and were decreasing from the high value center to the bay center $(1.40 \mu \mathrm{g} \mathrm{L}-1)$ and the coastal waters in the north of the bay (1.04 $\mu \mathrm{g} \mathrm{L-1)}$ (Fig. 2). The third high value of As contents was in Site C4 (2.06 $\mu \mathrm{g} \mathrm{L-1)}$ in the estuary of Loushan River, and the contour lines of As contents were forming a series of semi-concentric circles, and were decreasing from the high value center to the bay center $(1.40 \mu \mathrm{g} \mathrm{L}-1)$ and the coastal waters in the southwest of the bay (1.26 $\mu \mathrm{g} \mathrm{L-1)} \mathrm{(Fig.} \mathrm{2).} \mathrm{The} \mathrm{forth} \mathrm{high} \mathrm{value} \mathrm{of} \mathrm{As} \mathrm{contents} \mathrm{was} \mathrm{in} \mathrm{Site} \mathrm{C8}$ $(2.06 \mu \mathrm{g} \mathrm{L}-1)$ in the top of the bay in the northeast, and the contour lines of As contents were forming a series of semi-concentric circles, and were decreasing from the high value center to the bay center (1.40 $\mu \mathrm{g} \mathrm{L}-1)$ and the coastal waters in the southwest of the bay (1.26 $\mu \mathrm{g} \mathrm{L-1)}$ (Fig. 2).

As contents in August 1981 were 1.00-2.66 $\mu \mathrm{g} \mathrm{L}-1$. The first high value region of As contents was in Site D2, D3, D5, D6 and D9 (2.02-2.60 $\mu \mathrm{g} \mathrm{L-1)}$ in the estuary of Haibo River, and the contour lines of As contents were forming a series of semi-concentric circles, and were decreasing from the high value center to the bay mouth $(1.32 \mu \mathrm{g} \mathrm{L}-1)$ and the open waters $(1.12 \mu \mathrm{g} \mathrm{L}-1)$ (Fig. $3)$. The second high value region of As contents was in Site C2 and C6 (2.32-2.50 $\mu \mathrm{g} \mathrm{L-1)}$ in the estuary of Licun River, and the contour lines of As contents were forming a series of semi-concentric circles, and were decreasing from the high value center to the bay center $(1.96 \mu \mathrm{g}$ L-1) and coastal waters in the southwest of the bay (1.42 $\mu \mathrm{g} \mathrm{L}-1)$ (Fig. 3). The third high value region of As contents was in Site C4 and C7 (2.02-2.20 $\mu \mathrm{g} \mathrm{L-1)}$ in the estuary of Loushan River, and the contour lines of As contents were forming a series of semi-concentric circles, and were decreasing from the high value center to the bay center $(1.96 \mu \mathrm{g} \mathrm{L}-1)$ and coastal waters in the southwest of the bay (1.42 $\mu \mathrm{g} \mathrm{L-1)}$ (Fig. 3). The forth high value region of As contents was in Site B1 $(2.20 \mu \mathrm{g} \mathrm{L}-1)$ in the top of the bay in the northeast, and the contour lines of As contents were forming a series of semi-concentric circles, and were decreasing from the high value center to coastal waters in the southwest of the bay $(1.42 \mu \mathrm{g} \mathrm{L}-1)$ and the bay center (1.32 $\mu \mathrm{g} \mathrm{L-1)}$ (Fig. 3). 


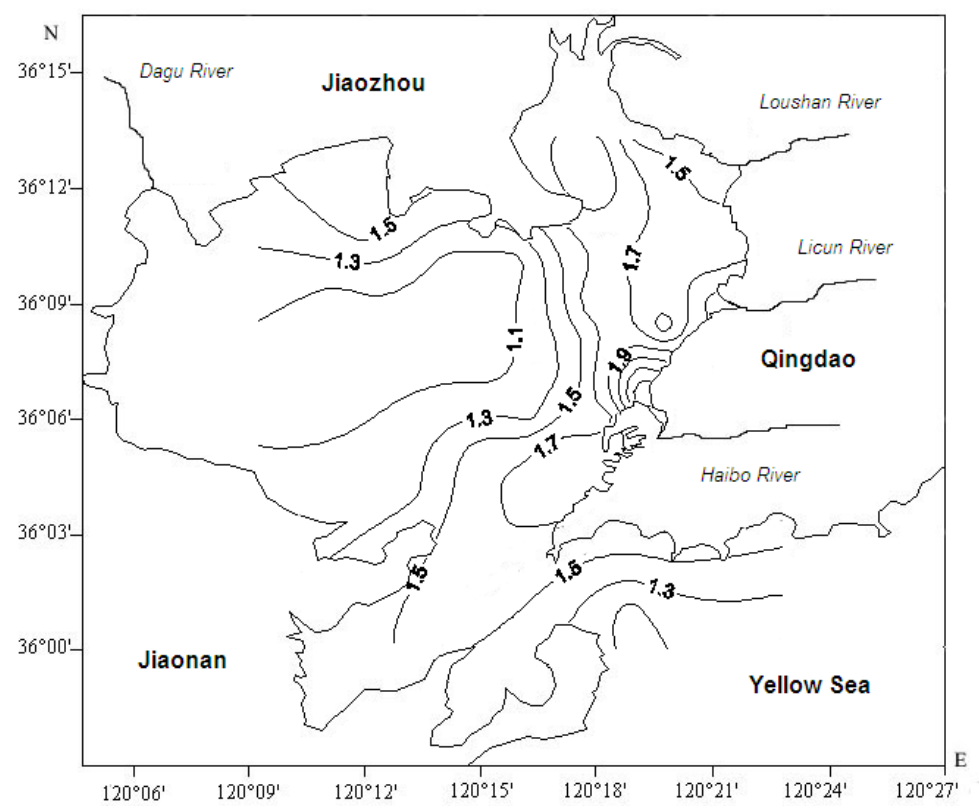

Fig. 2 Horizontal distributions of As contents in Jiaozhou Bay in April 1981/ $\mu$ g L-1

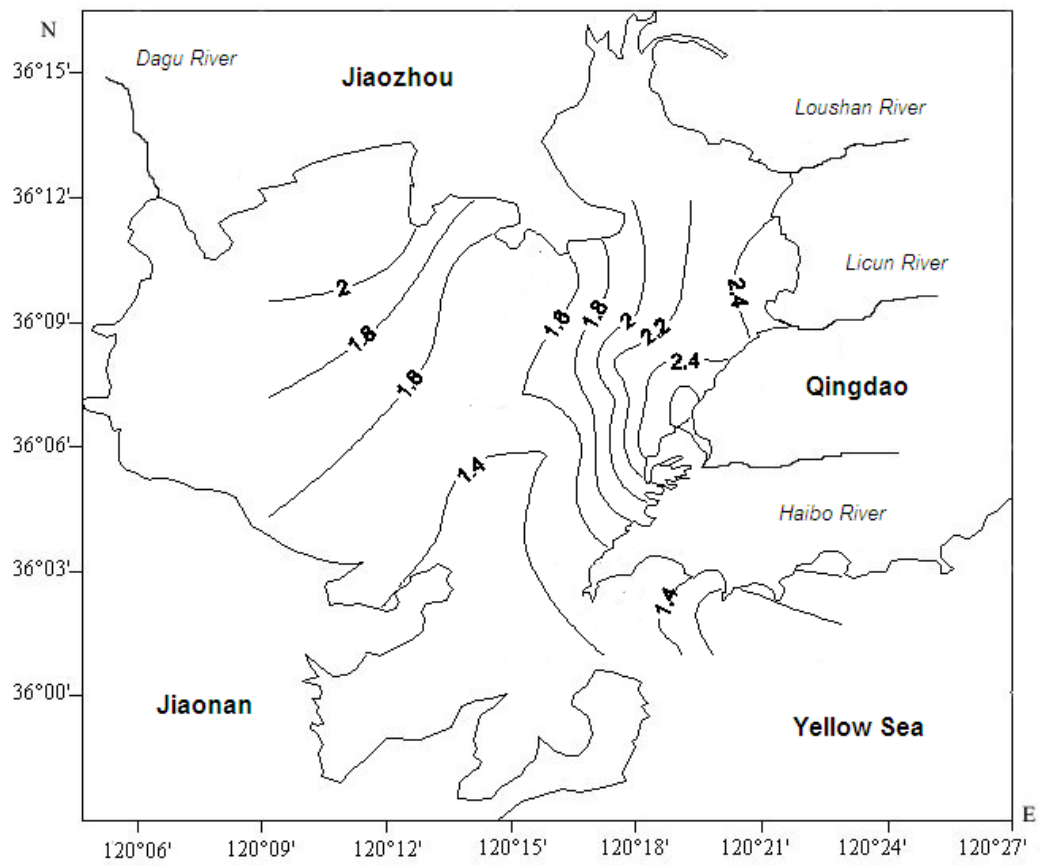

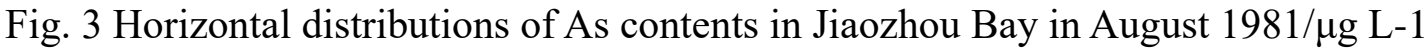

\section{Discussion}

\subsection{Sources and pollution levels of As.}

In according to the horizontal distributions of As, it could be found that the major As sources were overland runoff and river flow, whose source strengths were 2.06-2.20 $\mu \mathrm{g} \mathrm{L}^{-1}$ and 2.00-2.70 $\mu \mathrm{g}$ $\mathrm{L}^{-1}$, respectively (Table 1 ). It could be seen from Table 1 that the sources and source strengths of As were different in different locations and months. However, the source strengths were very closed.

In Jiaozhou Bay, As contents in April and August 1981 were 1.02-2.70 $\mu \mathrm{g} \mathrm{L-1}$ and 1.00-2.66 $\mu \mathrm{g}$ L-1, respectively. It could be seen form Fig. 2 and Fig. 3 that high As contents regions were occurring in different locations, yet were all confirmed to Class I (20.00 $\mu \mathrm{g} \mathrm{L-1)}$, in according to Sea Water Quality Standard (GB 3097-1997). Although the distributions of As contents were 
showing spatial and temporal variations, the pollution level of As in Jiaozhou Bay was till very slight in 1981. It could be considered as the background pollution level of As in this bay.

Table 1 As sources in Jiaozhou Bay

\begin{tabular}{|c|c|c|c|c|c|}
\hline \multicolumn{2}{|c|}{ Source } & \multicolumn{2}{c|}{ River flow } & \multicolumn{2}{c|}{ Overland runoff } \\
\hline Location & Haibo River & $\begin{array}{c}\text { Licun } \\
\text { River }\end{array}$ & $\begin{array}{c}\text { Loushan } \\
\text { River }\end{array}$ & $\begin{array}{c}\text { Northeast of } \\
\text { the bay }\end{array}$ & $\begin{array}{c}\text { North of } \\
\text { the bay }\end{array}$ \\
\hline April/ $/ \mathrm{g} \mathrm{L}^{-1}$ & 2.70 & 2.00 & 2.06 & 2.06 & \\
\hline August $/ \mu \mathrm{g} \mathrm{L}^{-1}$ & $2.02-2.60$ & $2.32-2.50$ & $2.02-2.20$ & & 2.20 \\
\hline
\end{tabular}

\subsection{Source input process of As.}

The source strengths of overland runoff were 2.06-2.20 $\mu \mathrm{g} \mathrm{L-1}$. The reason was that the land around Jiaozhou Bay had been polluted by As, and as a result the overland runoff was also polluted. The major reason was the application of As-containing agricultural chemicals. The source strengths of river flow were 2.00-2.70 $\mu \mathrm{g} \mathrm{L-1}$, and was higher than the source strength of overland runoff. This indicated that point source As particularly by industry waste water might had been responsible since 1981. The ranges of source strengths of overland runoff was following into the ranges of the source strengths of river. This indicated that the As input from overland runoff was a part of the As input from river flow.

In general, the source strengths of river flow in April and August 1981 were 2.00-2.70 $\mu \mathrm{g} \mathrm{L-1}$ and 2.02-2.66 $\mu \mathrm{g} \mathrm{L-1,} \mathrm{respectively.} \mathrm{This} \mathrm{indicated} \mathrm{that} \mathrm{the} \mathrm{river} \mathrm{flow} \mathrm{source} \mathrm{inputs} \mathrm{of} \mathrm{As} \mathrm{in} \mathrm{different}$ months were very closed. The source strengths of river flow in April and August 1981 were $2.06 \mu \mathrm{g}$ L-1 and $2.20 \mu \mathrm{g} \mathrm{L-1}$, respectively. This indicated that the overland runoff source inputs of As in different months were also very closed. As a whole, the source strengths of Cd inputs were very closed in different months as $2.00-2.70 \mu \mathrm{g} \mathrm{L}-1$. This indicated that the inputs of As from different sources were continuous and stable. Hence, more attentions should be payed to monitor the contents of As in overland runoff and river flow, as well as the retention and accumulation of As in soil and river bed.

\section{Conclusion}

As contents in Jiaozhou Bay in April and August 1981 were 1.02-2.70 $\mu \mathrm{g} \mathrm{L}-1$ and 1.00-2.66 $\mu \mathrm{g}$ L-1, respectively, and were all confirmed to Class I. The major As sources were overland runoff and river flow, whose source strengths were 2.06-2.20 $\mu \mathrm{g} \mathrm{L-1}$ and 2.00-2.70 $\mu \mathrm{g} \mathrm{L-1}$, respectively. It could be seen from Table 1 that the sources and source strengths of As were different in different locations and months. However, the source strengths were very closed. The inputs of As from different sources were continuous and stable. Hence, more attentions should be payed to monitor the contents of As in overland runoff and river flow, as well as the retention and accumulation of As in soil and river bed.

\section{Acknowledgement}

This research was sponsored by Research Projects of Guizhou Nationalities University ([2014]02), Research Projects of Guizhou Province Ministry of Education (KY [2014] 266), Research Projects of Guizhou Province Ministry of Science and Technology (LH [2014] 7376).

\section{References}

[1] Yang DF, Song WP, Chen ST, et al.: Coastal Engineering, Vol.31 (2012), p. 47-55. (in Chinese)

[2] Yang DF, Zhao YH, Piao ZG, et al.: Ocean Development and Management, Vol. 31 (2014), p. 109-112. (in Chinese)

[3] Yang DF, Zhu SX, Wang FY, et al.: Meterological and Environmental Research, Vol. 5 (2014), p. 24-26. 
[4] Yang DF, Chen Y, Gao ZH, et al.: Chinese Journal of Oceanology and Limnology, Vol. 23(2005), p. 72-90. (in Chinese)

[5] Yang DF, Wang FY, Gao ZH, et al.: Marine Science, Vol. 28 (2004), p. 71-74. (in Chinese)

[6] China's State Oceanic Administration: The specification for marine monitoring (Ocean Press, Beijiang 1991). (in Chinese) 